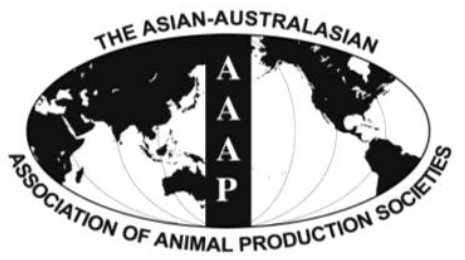

Asian-Aust. J. Anim. Sci.

Vol. 26, No. 1 : 43-49 January 2013

http://dx.doi.org/10.5713/ajas.2012.12401

www.ajas.info

pISSN 1011-2367 elSSN 1976-5517

\title{
Influence of Rabbit Sire Genetic Origin, Season of Birth and Parity Order on Doe and Litter Performance in an Organic Production System
}

\author{
Antonella Dalle Zotte and Gisella Paci ${ }^{1, *}$ \\ Department of Animal Medicine, Production and Health, University of Padova, Agripolis, 35020 Legnaro (PD), Italy
}

\begin{abstract}
The aim of this study was to compare both the performance of litters derived from two sire genetic origins (SGO), Vienna Blue (VB) and Burgundy Fawn (BF), along successive seasons of birth (SB; winter, spring, summer and autumn), and doe reproductive performance in an organic production system. A total of fifty-eight does consisting of a mixture of crosses of several medium-large size breeds at different parity order (P, $1=$ nulliparous; $2=$ primiparous; $\geq 3=$ multiparous $)$ and twelve males $(6$ VB and 6 $\mathrm{BF})$ were housed indoors at environmental conditions that followed seasonality. An extensive reproductive rhythm was used and kits were weaned at $46 \pm 6 \mathrm{~d}$ of age. Doe reproductive performance and the data of 105 litters (55 from VB and 50 from BF SGO) were recorded throughout the SB. No statistically significant differences related to SGO effect were observed. As regards parity order, multiparous does showed higher live weights $(\mathrm{LW})(\mathrm{p}<0.05)$, total born $(\mathrm{p}<0.01)$, total born alive $(\mathrm{p}<0.05)$ per delivery, and litter weight of born alive $(p<0.05)$, but lower milk output at 21 st $d$ than primiparous does $(p<0.05)$. The extensive reproductive rhythm mainly increased litter performance at birth in multiparous does but was not sufficient to permit a complete recovery of body reserves lost during lactation. Autumn SB negatively affected doe LW variation between deliveries. The number of pups born and born alive per delivery $(\mathrm{p}<0.05)$ and litter size at $21 \mathrm{~d}$ of age and at weaning $(\mathrm{p}<0.01)$ were lower during hot SB. Due to the lower litter size of pups born in summer and autumn, their individual weight at $21 \mathrm{st} d$ of age and daily individual growth rate 0 to $21 \mathrm{~d}$ were higher than those of pups born in winter $(\mathrm{p}<0.001)$. Litter performance at $21 \mathrm{st} \mathrm{d}$ of age and individual pup pre-weaning growth rate were poorer for those born in spring than in other seasons due to the harmful effects of increased environmental temperatures. SB affected most of the performance traits of does and young rabbits reared under the organic farming system. The rabbits seemed better suited to organic rearing conditions during winter than in other seasons. The worst results overall were obtained in the spring SB, whereas the hot SB negatively affected both doe energy balance and prolificacy. In conclusion, the pups of the 2 SGO showed good pre-weaning performance and seemed suited to the organic rabbit production system. (Key Words: Rabbit, Organic Production System, Reproduction, Genetic Origin)
\end{abstract}

\section{INTRODUCTION}

Organic rabbit production in Italy must follow the guidelines for organic livestock systems (Council Regulation (EC) No. 1804/1999) and those of two official certification organisms (ICEA, 2007; AIAB, 2012). Only pure breeds, their first generation crosses, and local population are admitted, and red-eye breeds are forbidden. The presence of a large number of animal biodiversity is the basis for the extensive production system, and for this

\footnotetext{
* Corresponding Author: Gisella Paci. Tel: +39-050-2216903, Fax: +39-050-2216901, E-mail: gpaci@ vet.unipi.it

${ }^{1}$ Department of Veterinary Sciences, University of Pisa Viale Piagge 2, 56100 Pisa, Italy.

Submitted Jul. 18, 2012; Accepted Sept. 15, 2012; Revised Oct. 8, 2012
}

reason it is important to maintain pure breeds, crossed breeds, and local populations that are well suited to preexisting environmental conditions. Furthermore, the choice of the breed must primarily consider resistance to disease and slow growth, even if reproductive traits and litter performance must be also taken into account. Over the last decade, several authors have studied the effects of alternative and organic rearing systems on the productive live performance, carcass and meat quality of rabbits derived from hybrids, pure breeds or local populations, but only a few have focused on reproductive performance (Cavani et al., 2000, 2004; Dal Bosco et al., 2000, 2002, 2003; Paci et al., 2004, 2005; Pla, 2008; D'Agata et al., 2009; Dalle Zotte et al., 2009; Princz et al., 2009). Many scientific papers and reviews report the effect of season and 
parity order on reproductive performances of does and productive performances of litters derived from hybrid lines reared under intensive system (Rommers et al., 1999; Marai et al., 2002; Xiccato et al., 2004; Fortun-Lamothe, 2006; Rebollar et al., 2009; Castellini et al., 2010; Villalobos et al., 2010; Szendrö et al., 2012), whereas these effects on purebred rabbit does, unselected for high production, and extensively reared are scarce (Paci et al., 2003). The information concerning the effect of the sire genetic origin on litter traits of synthetic lines, native and coloured breeds are also limited (Ozimba and Lukefahr, 1991; Khalil and Al-Saef, 2008; Piles et al., 2008a, b; Szendrő et al., 2010, 2012).

The aim of this study was to compare the performance of litters derived from two sire genetic origins, Vienna Blue and Burgundy Fawn, along successive rearing seasons, and doe reproductive performance in an organic production system.

\section{MATERIAL AND METHODS}

\section{Animals and housing system}

The trial was carried out in a farm certified for organic production located in Lombardia region, Italy (Azienda Agricola "Noi e la Natura", www.noielanatura.it) in 2004 from January to November.

A total of fifty-eight rabbit does at different parity order ( $\mathrm{P} ; 1=$ nulliparous; $2=$ primiparous; $\geq 3=$ multiparous $)$ and twelve males were involved. The maternal genetic origin was a mixture of crosses of several medium-large size breeds, California and New Zealand White excluded, according to an Italian official certification organism "Associazione Italiana per l'Agricoltura Biologica" (AIAB). The sire genetic origins (SGO) were Vienna Blue (VB; $n=$ 6) and Burgundy Fawn (BF; n = 6) introduced from an outside source at 8 weeks of age.

Does and sires were housed indoor in the same building supplied with a forced-ventilation system and natural lighting. During the experiment, environmental conditions followed seasonality with temperatures ranging from $10^{\circ} \mathrm{C}$ to $30^{\circ} \mathrm{C}$ and relative humidity from 60 to $75 \%$. The does were housed individually in wire cages $(810 \times 60 \times 33 \mathrm{~cm})$ with plastic slat floor according to the directives of EC Regulation 1804/1999 and the AIAB (2012). External nest boxes, containing a $2 \mathrm{~cm}$ layer of sanitized wood shavings, were provided at $28 \mathrm{~d}$ of gestation for kindling and nursing the kits up to weaning. Litters were equalised at birth by cross-fostering ( 8 to 10 pups per litter).

\section{Management}

An organic pelleted diet was given ad libitum to rabbit does and litters during the experimental period. Males were first mated at 5 months of age; nulliparous females were first mated at 3.5 months of age through natural mating. The does were randomly halved and the two groups were assigned to one of the two sire lines for the duration of the experiment.

Does were re-offered to the male 31 to $36 \mathrm{~d}$ after each delivery and pregnancy diagnosis through abdominal palpation took place $15 \mathrm{~d}$ after each mating. Does diagnosed not pregnant were returned to another buck of the designated sire line for re-mating. The females were remated three times until diagnosed as pregnant, after the third negative mating, the females were culled. Along the trial 14 does mated with BF (5 at first, 7 at second, 1 at third and 1 at fourth kindling) and 12 does mated with VB (7 at first, 4 at second and 1 at third kindling) were culled and replaced by other does not previously mated with the males object of study.

The kits, born from January to November, were weaned at $46 \pm 6 \mathrm{~d}$ of age but weaning occurred in two steps: at $35 \mathrm{~d}$ of age, the litters were moved to a collective cage in front of the mother that maintained the litter unit before being moved again to the collective cages located in the fattening building. The free suckling system was applied; nest boxes were inspected every morning and dead rabbits were removed.

\section{Reproductive data recording}

Doe reproductive performance and the data of 105 litters (55 litters from VB and 50 litters from BF SGO) were recorded throughout the seasons of birth (SB) (winter, spring, summer and autumn). Doe live weight was measured after each delivery. Day of delivery, number of total born, and born-alive per delivery, litter weight of born alive, litter size and weight at $21 \mathrm{~d}$ of age, pre-weaning mortality, weaning age, litter size, and weight at weaning were also recorded.

The following data were then calculated: fertility rate (percentage of deliveries/mating), delivery interval and doe LW variation between deliveries, milk output at $21 \mathrm{st} d$ of lactation (difference in litter body weight measured before and after suckling at $21 \mathrm{~d}$ of age), individual weight of born alive, at $21 \mathrm{~d}$ of age, and at weaning, and daily individual growth rate in ranges of 0 to $21 \mathrm{~d}, 22 \mathrm{~d}$-weaning, and preweaning ( 0 -weaning).

\section{Chemical analysis}

Throughout the trial, the organic diet was sampled for chemical analysis four times at each batch change (Table 1). AOAC procedures (2000) were used to determine in duplicate dry matter (DM; 934.01), ash (942.05), crude protein (CP; 976.05), crude fibre (CF; 978.10), neutral detergent fibre (NDF; 2,000.04), acid detergent fibre (ADF), and acid detergent lignin (ADL; 973.18) by using the Ankom Technology (Macedon, NY 14502) with filter bags 
Table 1. Chemical composition of the organic diet fed to does and litters $(\%$ as fed)

\begin{tabular}{lc}
\hline & Organic diet $^{1}$ \\
\hline Dry matter (DM, \%) & 92.01 \\
Crude protein (CP, \%) & 13.2 \\
Ether extract (EE, \% & 3.9 \\
Crude fibre (CF, \%) & 14.4 \\
Ash (\%) & 8.7 \\
NDF (\%) & 29.1 \\
ADF (\%) & 17.0 \\
ADL (\%) & 3.0 \\
Ca (\%) & 1.81 \\
P (\%) & 0.60 \\
Gross energy (GE, MJ/kg) & 16.35 \\
\hline
\end{tabular}

${ }^{1}$ Average.

(F57). Ether extract (EE; 920.39) was determined after acidhydrolysis. Gross energy (GE) was determined by adiabatic bomb calorimeter (ISO, 1998).

\section{Statistical analysis}

ANOVA was performed using the SAS (2007) program by including the SGO (VB, BF) the season of birth (SB), the parity $(\mathrm{P})$, and their interactions, for fertility rate only SGO effect was considered. No statistically significant interactions were observed for the considered parameters with exception of SGOxP interaction that resulted statistically significant $(\mathrm{p}<0.05)$ only for the variable "individual weight of born alive".

The statistical significance of the differences was assessed with the Tukey test (SAS, 2007).

\section{RESULTS AND DISCUSSION}

Interaction among main factors was not significant with exception for the SGOxP interaction $(\mathrm{p}<0.05)$ for individual weight of born alive pups (Figure 1) and thus Tables do not

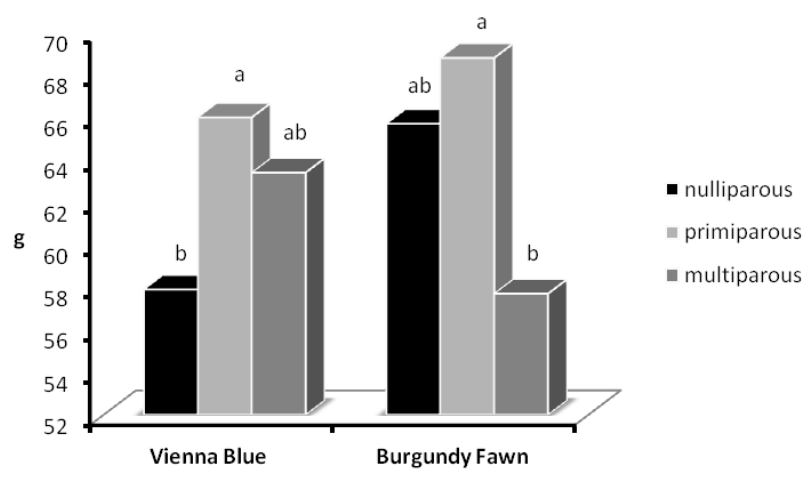

Figure 1. Effect of SGOxP interaction on individual weight of born alive $(\mathrm{p}<0.05)$.

report the significance of the interaction.

Table 2, 3 and 4 summarize the effects of sire genetic origin (SGO), season of birth (SB), and parity order (P) on doe reproductive performance and on litter size and litter weight at birth, at $21 \mathrm{~d}$, and at weaning, and throughout the 10 months of monitoring.

No significant differences related to the SGO effect were observed for all parameters.

The SB affected almost all the studied parameters. Considering doe LW variations between deliveries (Table 2), a significant LW loss in autumn SB was observed, whereas in winter and spring SB the doe energy balance was positive $(-8.18$ vs 2.75 and $0.22 \%$, respectively; $\mathrm{p}<0.05)$. The slight doe LW loss during summer SB might be explained by the reduced appetite and consequent lower feed intake at moderately high temperatures that induces does to mobilize their body reserves to satisfy their production needs and leads to lower live body weight at kindling (Nardone et al., 2010). The higher doe LW loss during autumn SB could depend on the inability to recover the negative effect of heat suffered during the previous season combined with the energy mobilization required for greater milk production.

Litter size at birth was also affected by SB. The

Table 2. Effect of sire genetic origin (SGO), season of birth (SB) and parity order (P) on the reproductive performances of rabbit does (n $=58$ ) and on litter size and weight at birth

\begin{tabular}{|c|c|c|c|c|c|c|c|c|c|c|c|c|c|}
\hline & \multicolumn{2}{|c|}{$\begin{array}{c}\text { Sire genetic origin } \\
\text { (SGO) }\end{array}$} & \multicolumn{4}{|c|}{ Season of birth (SB) } & \multicolumn{3}{|c|}{ Parity (P) } & \multicolumn{3}{|c|}{ p-value } & \multirow{2}{*}{ RMSE } \\
\hline & $\begin{array}{l}\text { Vienna } \\
\text { Blue }\end{array}$ & $\begin{array}{l}\text { Burgundy } \\
\text { Fawn }\end{array}$ & Winter & Spring & Summer & Autumn & Nulliparous & Primiparous & Multiparous & SGO & SB & $\mathrm{P}$ & \\
\hline Observations (n) & 61 & 60 & 35 & 43 & 29 & 14 & 42 & 25 & 54 & & & & \\
\hline Fertility rate $(\%)$ & 84.0 & 82.8 & - & - & - & - & - & - & - & ns & - & - & 19.3 \\
\hline Average liveweight at delivery (g) & 4,205 & 4,297 & 4,289 & 4,295 & 4,208 & 4,214 & $4,122^{\mathrm{b}}$ & $4,280^{\mathrm{ab}}$ & $4,352^{\mathrm{a}}$ & ns & ns & $*$ & 423 \\
\hline Interval between deliveries (d) & 62.40 & 67.40 & 67.1 & 72.8 & 61.3 & 58.4 & 64.2 & 61.8 & 68.7 & ns & ns & ns & 17.2 \\
\hline LW variation between deliveries (\%) & -0.07 & -2.70 & $2.75^{\mathrm{a}}$ & $0.22^{\mathrm{a}}$ & $-0.33^{\mathrm{ab}}$ & $-8.18^{\mathrm{b}}$ & 0.41 & -1.52 & -3.05 & ns & $*$ & ns & 5.89 \\
\hline Total born/delivery (n) & 8.40 & 8.30 & $9.5^{\mathrm{a}}$ & $8.6^{\mathrm{ab}}$ & $7.8^{\mathrm{b}}$ & $7.5^{\mathrm{b}}$ & $8.0^{\mathrm{B}}$ & $7.8^{\mathrm{B}}$ & $9.4^{\mathrm{A}}$ & ns & $*$ & $* *$ & 2.32 \\
\hline Born alive/delivery (n) & 8.30 & 8.30 & $9.4^{\mathrm{a}}$ & $8.5^{\mathrm{ab}}$ & $7.8^{\mathrm{b}}$ & $7.5^{\mathrm{b}}$ & $8.0^{\mathrm{b}}$ & $7.8^{\mathrm{b}}$ & $9.1^{\mathrm{a}}$ & ns & $*$ & $*$ & 2.28 \\
\hline Still-born/delivery (n) & 0.10 & 0.06 & 0.14 & 0.17 & 0.00 & 0.01 & 0.05 & 0.00 & 0.24 & ns & ns & ns & 0.73 \\
\hline Milk output at 21 st d (g) & 241 & 241 & 251 & 227 & 223 & 264 & $226^{\mathrm{b}}$ & $274^{\mathrm{a}}$ & $224^{\mathrm{b}}$ & ns & ns & $*$ & 69 \\
\hline Litter weight of born alive (g) & 501 & 501 & 535 & 503 & 460 & 505 & $479^{\mathrm{b}}$ & $478^{\mathrm{b}}$ & $546^{\mathrm{a}}$ & ns & ns & $*$ & 124 \\
\hline Individual weight of born alive ( $\mathrm{g}$ ) & 62.5 & 64.1 & $58.1^{\mathrm{b}}$ & $62.2^{\mathrm{ab}}$ & $63.6^{\mathrm{ab}}$ & $69.1^{\mathrm{a}}$ & 61.8 & 67.4 & 60.6 & ns & $*$ & ns & 12.0 \\
\hline Litter size at crossfostering $(n)$ & 8.80 & 8.30 & $9.6^{\mathrm{A}}$ & $8.9^{\mathrm{AB}}$ & $7.9^{\mathrm{B}}$ & $7.9^{\mathrm{B}}$ & 8.2 & 8.4 & 9.1 & ns & ** & ns & 1.8 \\
\hline
\end{tabular}

${ }^{1}$ Residual means standard error; ** $\mathrm{p}<0.01 ; * \mathrm{p}<0.05$. 
Table 3. Effect of genetic origin (SGO), of season of birth (SB) and parity order (P) on the litter size and weight at $21 \mathrm{~d}$

\begin{tabular}{|c|c|c|c|c|c|c|c|c|c|c|c|c|c|}
\hline & \multicolumn{2}{|c|}{$\begin{array}{l}\text { Sire genetic origin } \\
\text { (SGO) }\end{array}$} & \multicolumn{4}{|c|}{ Season of birth (SB) } & \multicolumn{3}{|c|}{ Parity (P) } & \multicolumn{3}{|c|}{ p-value } & \multirow{2}{*}{$\operatorname{RMSE}^{1}$} \\
\hline & $\begin{array}{l}\text { Vienna } \\
\text { Blue }\end{array}$ & $\begin{array}{l}\text { Burgundy } \\
\text { Fawn }\end{array}$ & Winter & Spring & Summer & Autumn & Nulliparous & Primiparous & Multiparous & SGO & SB & $\mathrm{P}$ & \\
\hline Litter (n) & 55 & 50 & 31 & 40 & 21 & 13 & 38 & 22 & 45 & & & & \\
\hline Litter size at $21 \mathrm{~d}(\mathrm{n})$ & 8.1 & 7.6 & $8.8^{\mathrm{A}}$ & $8.2^{\mathrm{AB}}$ & $6.9^{\mathrm{C}}$ & $7.5^{\mathrm{BC}}$ & 7.7 & 7.8 & 8.0 & ns & $* *$ & ns & 1.68 \\
\hline Litter weight at $21 \mathrm{~d}(\mathrm{~g})$ & 2,697 & 2,619 & $2,778^{\mathrm{a}}$ & $2,487^{\mathrm{b}}$ & $2,545^{\mathrm{ab}}$ & $2,823^{\mathrm{a}}$ & 2,577 & 2,738 & 2,660 & ns & $*$ & ns & 454 \\
\hline Individual weight at $21 \mathrm{~d}(\mathrm{~g})$ & 342 & 365 & $323^{\mathrm{B}}$ & $313^{\mathrm{B}}$ & $387^{\mathrm{A}}$ & $393^{\mathrm{A}}$ & 351 & 367 & 342 & ns & $* * *$ & ns & 65 \\
\hline $\begin{array}{l}\text { Daily individual } \\
\text { growth rate } 0 \text { to } 21 \mathrm{~d}(\mathrm{~g} / \mathrm{d})\end{array}$ & 13.2 & 14.0 & $12.3^{\mathrm{B}}$ & $11.8^{\mathrm{B}}$ & $14.9^{\mathrm{A}}$ & $15.3^{\mathrm{A}}$ & 13.6 & 14.3 & 12.9 & $\mathrm{~ns}$ & $* * *$ & $\mathrm{~ns}$ & 2.97 \\
\hline
\end{tabular}

${ }^{1}$ Residual means standard error; $* * * \mathrm{p}<0.001 ; * * \mathrm{p}<0.01 ; * \mathrm{p}<0.05$

numbers of pups born/delivery and born alive/delivery were higher in winter than in autumn and summer SB (9.5 vs 7.5 and 7.8 pups; 9.4 vs 7.5 and 7.8 pups, respectively; $p<0.05$, Table 2); similar results were obtained also when considering litter size adjusted by cross-fostering (9.6 vs 7.9 and 7.9 pups; $\mathrm{p}<0.01$, Table 2). The higher litter size constituted by cross-fostering, mainly in winter SB, depended on the decision of the breeder to keep all newborn and equalize the litters to the maximum in order to cover production costs. The SB effect on litter size at birth observed in this study confirms those reported elsewhere (Ayyat and Marai, 1998; Marai et al., 2002; Villalobos et al., 2010; Szendrő et al., 2012). The decrease in prolificacy at high environmental temperature depends on a great number of physiological events that may lead to significant reductions in total born and an increase in still-born pups. High environmental temperature has also been shown to compromise oocyte growth and embryo development while increasing embryo mortality (Wolfenson et al., 2000; Marai et al., 2006; Hansen, 2007). The reduced prolificacy observed in autumn may also depend on the effect of the heat stress suffered by the does during the previous hot season. High environmental temperatures are known to lead to reductions in feed intake that impair doe performance and alter the physiological functions that affect reproductive efficiency as a result (Lebas et al., 1986; Lacetera et al., 2003; Fortun-Lamothe, 2006).

$\mathrm{SB}$ also affected the individual weight of born alive pups: born alive pups born in winter SB were significantly lighter than those born in autumn SB (58.1 vs $69.1 \mathrm{~g}$; $\mathrm{p}<0.05$, Table 2), probably due to differences in litter size. Birth weight is influenced by several factors during pregnancy, among which, the number of fetuses in the uterine horn plays an important role (Rommers et al., 1999).

Parity order (P) influenced some of the variables considered (Table 2). The LW of multiparous does was significantly higher than that of nulliparous does $(4,352$ vs $4,122 \mathrm{~g} ; \mathrm{p}<0.05)$. The lighter LW observed in the nulliparous does is related to age: when does start their reproductive life, they have not yet usually achieved total body development (Rebollar et al., 2009). However, the values of LW variation between kindlings indicate an increase of the energy deficit with $\mathrm{P}$ despite an increase in doe LW or any extensive reproductive rhythm adopted. Thus, the extensive reproductive rhythm used in accordance with organic farming guidelines does not appear efficient in reducing doe energy deficits, even regardless of parity order. In these females, not selected for high productive and reproductive performances, the after weaning mating was not sufficient to permit a complete recovery of the body reserves lost during lactation. These findings were observed also by other authors in multiparous hybrids, which were unable to cover the requirements for reproduction without mobilizing body energy (Pascual et al., 2000).

The milk output registered at 21 st $d$ of lactation (Table 2) was lower in nulliparous and multiparous than in

Table 4. Effect of sire genetic origin (SGO), of season of birth (SB) and parity order (P) on the litter size, weight and mortality at weaning

\begin{tabular}{|c|c|c|c|c|c|c|c|c|c|c|c|c|c|}
\hline & \multicolumn{2}{|c|}{ Sire genetic origin (SGO) } & \multicolumn{4}{|c|}{ Season of birth (SB) } & \multicolumn{3}{|c|}{ Parity $(\mathrm{P})$} & \multicolumn{3}{|c|}{ p-value } & \multirow[b]{2}{*}{$\operatorname{RMSE}^{1}$} \\
\hline & $\begin{array}{c}\text { Vienna } \\
\text { Blue }\end{array}$ & $\begin{array}{l}\text { Burgundy } \\
\text { Fawn }\end{array}$ & Winter & Spring & Summer & Autumn & Nulliparous & Primiparous & Multiparous & SGO & SB & $\mathrm{P}$ & \\
\hline Litter (n) & 55 & 50 & 31 & 40 & 21 & 13 & 38 & 22 & 45 & & & & \\
\hline Weaning age (d) & 46.9 & 45.9 & 44.9 & 47.5 & 47.0 & 46.2 & 45.8 & 46.5 & 46.9 & ns & ns & ns & 6.2 \\
\hline Litter size at weaning (n) & 7.4 & 7.0 & $8.4^{\mathrm{A}}$ & $7.5^{\mathrm{AB}}$ & $6.0^{\mathrm{C}}$ & $7.0^{\mathrm{BC}}$ & 7.2 & 6.9 & 7.6 & ns & $* * *$ & ns & 1.76 \\
\hline Litter weight at weaning (g) & 7,772 & 7,184 & $8,490^{\mathrm{a}}$ & $7,240^{\mathrm{b}}$ & $6,789^{\mathrm{b}}$ & $7,393^{\mathrm{ab}}$ & 7,221 & 7,377 & 7,837 & ns & $*$ & ns & 2,086 \\
\hline Individual weight at weaning (g) & 1,054 & 1,040 & $1,017^{\mathrm{b}}$ & $971^{\mathrm{b}}$ & $1,142^{\mathrm{a}}$ & $1,059^{\mathrm{ab}}$ & 1,011 & 1,087 & 1043 & ns & $*$ & ns & 181 \\
\hline $\begin{array}{l}\text { Daily individual } \\
\text { growth rate } 22 \text { d-weaning }(\mathrm{g} / \mathrm{d})\end{array}$ & 26.5 & 25.5 & $29.0^{\mathrm{a}}$ & $23.7^{\mathrm{b}}$ & $27.0^{\mathrm{ab}}$ & $24.1^{\mathrm{ab}}$ & 25.4 & 25.7 & 26.8 & ns & $*$ & ns & 7.48 \\
\hline $\begin{array}{l}\text { Daily individual } \\
\text { pre-weaning growth rate }(\mathrm{g} / \mathrm{d})\end{array}$ & 21.0 & 21.0 & $21.2^{\mathrm{A}}$ & $19.0^{\mathrm{B}}$ & $22.8^{\mathrm{A}}$ & $21.1^{\mathrm{AB}}$ & 20.6 & 21.8 & 20.7 & ns & $* *$ & ns & 3.49 \\
\hline Pre-weaning mortality (\%) & 15.8 & 16.3 & 14.8 & 15.0 & 20.0 & 14.3 & 11.6 & 20.6 & 15.9 & $\mathrm{~ns}$ & $\mathrm{~ns}$ & ns & 15.8 \\
\hline
\end{tabular}

${ }^{1}$ Residual means standard error; *** $\mathrm{p}<0.001 ; * * \mathrm{p}<0.01 ; * \mathrm{p}<0.05$. 
primiparous does (226 and 224 vs $274 \mathrm{~g} / \mathrm{d} ; \mathrm{p}<0.05$ ). The low milk production of nulliparous does depended on their insufficient feed intake, which led to the consequent inability to cover lactation requirements (Xiccato et al., 2004; Fortun-Lamothe, 2006). The low milk output of multiparous does may also have been related to their body energy deficit, as denoted by the loss of weight and the higher litter size at birth. These results contrast with those reported by Xiccato et al. (2004), who indicated an increase of milk production with increasing $\mathrm{P}$ and litter size. It should be noted that the data reported in literature refer to hybrid does, which are selected for very high feed intake, whereas the does used in our research were unselected and for this reason unable to adjust their voluntary feed intake to their energy requirements (Pascual et al., 2000).

As concerns litter performance at birth (Table 2), multiparous doe litters were numerically larger in terms of both total born/delivery $(\mathrm{p}<0.01)$ and born alive/delivery $(\mathrm{p}<0.05)$, and also heavier $(\mathrm{p}<0.05)$ than those of nulliparous and primiparous does (9.4 vs 8.0 and 7.8 pups; 9.1 vs 8.0 and 7.8 pups; 546 vs 479 and 478 g, respectively). In multiparous does, the higher litter weight of born alive was due to the higher number of born alive at kindling and not to pup individual weight, as the latter did not differ significantly among P. Our findings are supported by other recent studies that considered multiparous females inseminated after weaning (Fortun-Lamothe, 2006; TheauClement, 2007; Castellini et al., 2010). In our study, does were mated with extensive reproductive rhythm, and therefore the negative effect of lactation on prolificacy was lacking and this led to improved litter parameters.

Data showing the statistically significant $(\mathrm{p}<0.05)$ SGOxP interaction for individual weight of born alive pups are reported in Figure 1. In VB SGO, the individual weight of born alive pups slightly increased, whereas in BF SGO it decreased significantly $(\mathrm{p}<0.05)$ with $P$. This individual birth weight decrease (from 68.8 to $57.7 \mathrm{~g}$, in primiparous and multiparous $\mathrm{BF}$, respectively) was probably related to the very high individual weight of pups of part of the does formerly primiparous.

Litter size, litter weight, individual weight, and daily individual growth rate were affected by SB also at $21 \mathrm{~d}$ of age (Table 3 ). In our study, the litter size at $21 \mathrm{~d}$ of age showed the lowest values in pups born in summer and autumn compared to those born in winter (6.9 and 7.5 vs $8.8 \mathrm{pups} / \mathrm{L}$, respectively; $\mathrm{p}<0.01)$. These results might be explained by the lower number of born alive/delivery observed in summer and autumn and by the slightly higher pre-weaning mortality registered in summer.

In rabbits, the negative consequences of high environmental temperatures are also seen during autumn with the impairment of production and reproduction (Ayyat et al., 1995; Ayyat and Marai, 1998; Marai et al., 2002; Marai and Rashwan, 2004).

$\mathrm{SB}$ affected also individual weight at $21 \mathrm{st} \mathrm{d}$ of age and the daily individual growth rate 0 to $21 \mathrm{~d}$ of age, creating heavier rabbits and higher growth rate in rabbits born in summer and in autumn than in the other two previous seasons (387 and $393 \mathrm{~g}$ vs 323 and $313 \mathrm{~g}, \mathrm{p}<0.001 ; 14.9$ and $15.3 \mathrm{~g} / \mathrm{d}$ vs 12.3 and $11.8 \mathrm{~g} / \mathrm{d}, \mathrm{p}<0.001$; respectively).

Individual weight at $21 \mathrm{st} \mathrm{d}$ of age is the variable most related to milk output because up to this time the pups consume practically only milk, which contributes to both their growth and development and their survival before weaning (Villalobos et al., 2010). Moreover, individual milk intake is highly dependent on the size of the suckling litter and the milk produced by the doe, which latter is reduced by high environmental temperatures and this reduces doe feed intake in turn.

The best growth of the rabbits born in summer and autumn was ascribed to the significantly lower litter size in these two SB, which provided more milk/pup, and also to the more favourable environmental temperatures during growth, particularly for rabbits born in autumn. On the contrary, the spring SB provided the worst litter performance at $21 \mathrm{st} \mathrm{d}$ of age because both litters and does had to cope with rising environmental temperatures.

The growth performance of young rabbits at weaning and pre-weaning mortality are summarized in Table 4. Litter size, litter weight, and individual body weight, and daily individual growth rate from $22 \mathrm{~d}$ to weaning and during the pre-weaning period were affected only by SB. The litter size of rabbits at weaning was still higher in winter than in summer SB (8.4 vs 6.0 rabbits/litter; $\mathrm{p}<0.001)$.

Individual weaning weight was higher in rabbits born in summer than in winter and spring $(1,142 \mathrm{vs} 1,017$ and $971 \mathrm{~g}$, respectively; $\mathrm{p}<0.05)$ but the litter weight at weaning was higher in rabbits born in winter due to litter sizes that were higher than those born in spring and summer $(8,490$ vs 7,240 and $6,789 \mathrm{~g} /$ litter; $\mathrm{p}<0.05$ ), in this way confirming the results found in literature (Ayyat and Marai, 1998; Marai et al., 2002; Marai et al., 2006).

The best individual growth rate during 22 d-weaning was observed in rabbits born in winter; the worst was seen in those born in spring $(29.0$ vs $23.7 \mathrm{~g} / \mathrm{d} ; \mathrm{p}<0.05)$ due to higher solid food intake at lower environmental temperatures.

The individual growth rate of rabbits during the entire pre-weaning period was highest in rabbits born in summer and in winter because they missed the hot season, and was lowest in those born in spring (22.8 and 21.2 vs $19.0 \mathrm{~g} / \mathrm{d}$; $\mathrm{p}<0.01$ ) when young rabbit growth was negatively affected by the heat. This worst rabbit pre-weaning performance observed in the spring SB has also been recently reported 
by Villalobos et al. (2010).

\section{CONCLUSIONS}

After evaluating the reproductive and productive performance of does and their litters it can be concluded that the two sire breeds tested (Vienna Blue and Burgundy Fawn) are comparable and seem to be suitable to the organic production system. The season of birth affected most of the performances of does and young rabbits reared with the organic farming system, and the rabbits seemed better suited to these rearing conditions during winter than in other seasons. The results obtained seem promising: after an initial difficulty in coping with rising temperatures in spring, both does and litters showed a moderately good ability in adapting to adverse environmental conditions, and this was probably due to the genetic origin.

\section{ACKNOWLEDGEMENTS}

Research funded by MIUR (PRIN 2002 - Prot. 2002078279_004). The certified organic farm "Noi e la Natura" http://www.noielanatura.it is greatly acknowledged.

\section{REFERENCES}

AIAB. 2012. Associazione Italiana per l'Agricoltura Biologica Disciplinare garanzia AIAB Italia (http://www.aiab.it).

AOAC. 2000. Official methods of analysis. 17th edn. Association of Official Analytical Chemists, Gaithersburg, Maryland.

Ayyat, M. S., I. F. M. Marai and G. H. A. El-Sayiad. 1995. Genetic and nongenetic factors affecting milk production and preweaning litter traits of New Zealand White does, under Egyptian conditions. World Rabbit Sci. 3:119-124.

Ayyat, M. S. and I. F. M. Marai. 1998. Evaluation of application of the intensive rabbit production system under the subtropical conditions of Egypt. World Rabbit Sci. 6:213-217.

Castellini, C., A. Dal Bosco, M. Arias-Alvarez, P. L. Lorenzo, R. Cardinali and P. G. Rebollar. 2010. The main factors affecting the reproductive performance of rabbit does: a review. Anim. Reprod. Sci. 122:174-182.

Cavani, C., M. Bianchi, C. Lazzaroni, F. Luzi, G. Minelli and M. Petracci. 2000. Influence of type of rearing, slaughter age and sex on fattening rabbit: II Meat quality. World Rabbit Sci. 8:567-572.

Cavani, C., M. Bianchi, M. Petracci, T. G. Toschi, G. P. Parpinello, G. Kuzminsky, P. Morera and A. Finzi. 2004. Influence of open-air rearing on fatty acid composition and sensory properties of rabbit meat. World Rabbit Sci. 12:247-258.

Council Regulation (EC) No. 1804/1999 supplementing Regulation (EEC) No. 2092/91 on organic production of agricultural products and indications referring thereto on agricultural products and foodstuffs to include livestock production. CELEX-EUR Official Journal L 222, 24 August 1999, pp. 1-28. Website: europa.eu.eur18524.doc.
D’Agata, M., G. Preziuso, C. Russo, A. Dalle Zotte, E. Mourvaki and G. Paci. 2009. Effect of an outdoor rearing system on the welfare, growth performance, carcass and meat quality of a slow-growing rabbit population. Meat Sci. 83:691-696.

Dal Bosco, A., C. Castellini and M. Bernardini. 2000. Productive performance and carcass and meat characteristics of cage- or pen-raised rabbits. World Rabbit Sci. 8:579-583.

Dal Bosco, A., C. Castellini and C. Mugnai. 2002. Rearing rabbits on wire net floor or straw litter: behaviour, growth and meat qualitative traits. Livest. Prod. Sci. 75:149-156.

Dal Bosco, A., C. Castellini and C. Mugnai. 2003. Influenza del sistema di allevamento sul metabolismo energetico dei muscoli e sulla stabilità ossidativa della carne di coniglio. Riv. Coniglicoltura. 4:46-47.

Dalle Zotte, A., Z. Princz, Sz. Metzger, A. Szabó, I. Radnai, E. Biró-Németh, Z. Orova and Zs. Szendrö. 2009. Response of fattening rabbits reared under different housing conditions. 2. Carcass and meat quality. Livest. Sci. 122:39-47.

Fortun-Lamothe, L. 2006. Energy balance and reproductive performance in rabbit does. Anim. Reprod. Sci. 93:1-15.

Hansen, P. J. 2007. Explotation of genetic and physiological determinants of embryonic resistance to elevated temperature to improve embryonic survival in dairy cattle during heat stress. Theriogenology 68 (Suppl. 1):S242-S249.

ICEA. 2007. Istituto per la certificazione etica e ambientale. http://www.icea.info/en/

ISO. 1998. Animal feeding stuffs, animal products and faeces or urine. Determination of gross calorific value - Bomb calorimetric method. Reference number 9831.

Khalil, M. H. and A. M. Al-Saef. 2008. Methods, criteria, techniques and genetic responses for rabbit selection: a review. In: Proceedings of $9^{\text {th }}$ World Rabbit Congress. Verona, Italy. pp. $1-18$.

Lacetera, N., U. Bernabucci, B. Ronchi and A. Nardone. 2003. Physiological and productive consequences of heat stress. The case of dairy ruminants. Proceedings of the Symposium on interaction between Climate and Animal Production: EAAP Technical Series. 7:45-60.

Lebas, F., P. Coudert, R. Rouvier and H. De Rochambeau. 1986. The rabbit. Husbandry, Health and Production. FAO. Ed., Rome, Italy.

Marai, I. F. M., A. A. M. Habeeb and A. E. Gad. 2002. Rabbit's productive, reproductive and physiological performance traits as affected by heat stress: a review. Livest. Prod. Sci. 78:71-90.

Marai, I. F. M. and A. A. Rashwan. 2004. Rabbits behavioural response to climatic and managerial conditions - a review. Arch. Tierz. Dummerstorf 47:469-482.

Marai, I. F. M., A. A. Askar and L. B. Bahgat. 2006. Tolerance of New Zealand White and Californian doe rabbits at first parity to the sub-tropical environment of Egypt. Livest. Sci. 104:165172.

Nardone, A., B. Ronchi, N. Lacetera, M. S. Ranieri and U. Bernabucci. 2010. Effects of climate changes on animal production and sustainability of livestock systems. Livest. Sci. 130:57-69.

Ozimba, C. E. and S. D. Lukefahr. 1991. Comparison of rabbit breed types for postweaning litter growth, feed efficiency and survival performance traits. J. Anim. Sci. 69:3494-3500. 
Paci, G., E. Lisi, A. Maritan and M. Bagliacca. 2003. Reproductive performance in a local rabbit population reared under organic and conventional system. Ann. Fac. Med. Vet. Pisa 56:115-125.

Paci, G., E. Lisi, A. Cini and M. Bagliacca. 2004. Tecniche di allevamento e caratteristiche di conigli biologici prodotti in un'azienda certificata della Toscana. Riv. Coniglicoltura 5:1417.

Paci, G., A. Schiavone, E. Lisi, P. G. Peiretti, M. Bagliacca and P. P. Mussa. 2005. Meat quality characteristics in local population of rabbit reared with organic system. Proceedings of the 16th ASPA Congress. 4:562.

Pascual, J. J., C. Cervera and J. Fenandez-Carmona. 2000. The effect of dietary fat on he performance and body composition of rabbits in their second lactation. Anim. Feed Sci. Technol. 86:191-203.

Piles, M., Ll. Tusell, M. García-Tomás, M. Baselga, I. GarcíaIspierto, O. Rafel, J. Ramon and M. López-Bejar. 2008a. Genotype $X$ Sperm dosage interaction on reproductive performance after artificial insemination. 1. Male fertility. In Proceedings of $9^{\text {th }}$ World Rabbit Congress. Verona, Italy. pp. 118.

Piles, M., Ll. Tusell, M. García-Tomás, M. Baselga, I. GarcíaIspierto, O. Rafel, J. Ramon and M. López-Bejar. 2008b. Genotype X Sperm dosage interaction on reproductive performance after artificial insemination. 2 Male litter size. In Proceedings of $9^{\text {th }}$ World Rabbit Congress. Verona, Italy. pp. 227-232.

Pla, M. 2008. A comparison of the carcass traits and meat quality of conventionally and organically produced rabbits. Livest. Prod. Sci. 115:1-12.
Princz, Z., A. Dalle Zotte, Sz. Metzger, I. Radnai, E. Biró-Németh, Z. Orova and Zs. Szendrö. 2009. Response of fattening rabbits reared under different housing conditions. 1. Live performance and health status. Livest. Sci. 121:86-91.

Rebollar, P. G., M. A. Perez-Cabal, N. Pereda, P. L. Lorenzo, M. Arias-Alvarez and P. Garcia-Rebollar. 2009. Effects of parity order and reproductive management on the efficiency of rabbit productive systems. Livest. Sci. 121:227-233.

Rommers, J. M., B. Kemp, R. Meijerhof and J. P. T. M. Noordhuizen. 1999. Rearing management of rabbit does: a review. World Rabbit Sci. 7:125-138

SAS Institute Inc. 2007. JMP7 user's guide: Version 7. 2nd edn. SAS Institute Inc., Cary, North Carolina.

Szendrő, Zs., Z. Matics, Z. Gerencsér, I. Nagy, M. Lengyel, P. Horn and A. Dalle Zotte. 2010. Effect of dam and sire genotypes on productive and carcass traits of rabbits. J. Anim. Sci. 88:533-543.

Szendrő, Zs., K. Szendrő and A. Dalle Zotte. 2012. Management of reproduction on small, medium and large rabbit farms: a review. Asian-Aust. J. Anim. Sci. 25:738-748.

Theau-Clement, M. 2007. Preparation of the rabbit doe to insemination: a review. World Rabbit Sci. 15:61-80.

Villalobos, O., O. Guillen and J. Garcia. 2010. Effect of breeding system, cycle and cage size during fattening on rabbit doe and growing rabbit performance under heat stress. Animal 4:15681576.

Xiccato, G., A. Trocino, A. Sartori and P. I. Queaque. 2004. Effect of parity order and litter weaning age on the performance and body energy balance of rabbit does. Livest. Prod. Sci. 239-251.

Wolfenson, D., Z. Roth and R. Meidan. 2000. Impaired reproduction in feat-stressed cattle: basic and applied aspects. Anim. Reprod. Sci. 60-61:535-547. 